\title{
Changes in organic carbon stocks in soils under Scots pine (Pinus sylvestris L.) stands in northern Poland over 26 years
}

\author{
Grażyna Porębska1*, Jan Borzyszkowski1 ${ }^{1}$, Dariusz Gozdowski² \\ ${ }^{1}$ Institute of Environmental Protection - National Research Institute, Krucza 5/11D, 00-548 Warszawa, Poland \\ ${ }^{2}$ Warsaw University of Life Sciences - SGGW, Institute of Agriculture, Department of Biometry, Nowoursynowska 159, 02-776 Warszawa, Poland \\ * dr hab. Grażyna Porębska, e-mail: grazyna.porebska@ios.edu.pl, ORCID iD: https://orcid.org/0000-0002-3762-1682
}

\begin{abstract}
Received: 09.12.2020

Accepted: 30.07.2021

Associated editor: P. Sewerniak

\section{Keywords}

Forest soil

Carbon stocks

Vertical distribution

Long-term changes in soil organic carbon (SOC) are relevant to the carbon cycle and global warming in coming decades. The possibility of the increasing of carbon sequestration in forest soils is disputable as climate warming can accelerate carbon fluxes which affects the carbon stocks. Our study aimed at evaluating SOC stocks and its vertical distribution in forest soils over 26 years. Soils were sampled from genetic horizons in mature pine forest in northern Poland. The study was carried out on the same plots in 1992, 2008 and 2018. Organic carbon, total nitrogen and bulk density were determined at genetic soil horizons. SOC stocks were calculated in the $0-40 \mathrm{~cm}$ and 0-100 cm soil layers. The SOC stored to the depth of $40 \mathrm{~cm}$ was found to decrease by ca. $15 \%$ over 26 years. The SOC stocks decreased by 5\% in 0-40 cm layer and by $9 \%$ in $0-100 \mathrm{~cm}$ layer over the last ten years. About $84-88 \%$ of the total SOC stocks was found in the $0-40 \mathrm{~cm}$, out of which $40 \%$ was accumulated in the organic horizon. The results obtained indicate that no increase in SOC stocks in forest soils developed from sands may be expected over the next years, even though forests and forest soils represent a large reservoir of organic carbon.
\end{abstract}

\section{Introduction}

Forest soils store huge quantities of organic carbon (OC) due to many-year-long stand production cycles. Thus, it is not surprising that there is a growing interest whether and to what extent carbon dioxide $\mathrm{CO}_{2}$ binding in the biomass, and finally, carbon accumulation in forest soils may help alleviate the effect of global warming. Therefore, a great importance is attached to estimating both the amount of OC accumulated in soils and its stocks stored with the increasing stand age in the course of the production cycle.

The rate of biomass production and flux to the forest floor and, subsequently, of its transformation measured by the quantity of soil organic carbon (SOC), is subject to changes throughout the multiannual period of stand growth depending on its varying conditions. The key factors controlling the above processes embrace the soil properties (Schoenholtz et al., 2000; Moffat, 2003; Shukla et al., 2006; Martin et.al., 2011; Zornoza et al., 2015; Gruba and Socha, 2016) and climate, including mainly temperature and precipitation during the vegetation season and beyond (e.g. Allen et al., 2011; Prietzel and Christophel, 2014; Stergiadi et. al, 2016; Błońska and Lasota, 2017), as well as management practices and previous land use types (Dovydenko, 2004; Gross et al., 2018; Hou et al., 2019).
Research dealing with estimating $\mathrm{C}$ accumulation in forest soils and opportunities to enhance this accumulation covers multiple issues. Studies include the assessment of how different soil properties affect the quality of forest sites (e.g. Schoenholtz et al., 2000), dynamics of biomass production and accumulation throughout the period of stand growth (e.g. Liu et al., 2017; López-Marcos et al., 2018; Martinik et al., 2018; Bouriaud et al., 2019; Zhang et al., 2019), the rate of soil organic matter (SOM) decomposition and flux down into the soil profile (Hagedorn and Machwitz, 2007; Wickland and Neff, 2008; Schindlbacher et al., 2010), the assessment of $C$ stocks stored in individual genetic horizons and/or layers of varying thickness (Jobbagy and Jackson, 2000; Callesen et al., 2015; De Vos et al., 2015), as well as the development of various indicators which help estimating changes of a given process over time (Yigini and Panagos, 2016).

According to Grüneberg et al. (2014), it is hardly possible to accurately estimate the SOC stocks given the complexity of physical, chemical and biological processes, which control the $\mathrm{C}$ cycle in the soil, depending on the spatial scale wherein these processes are considered. The average SOC stocks estimated for the European forests were $108 \mathrm{t} \mathrm{C} \mathrm{ha}^{-1}$ in mineral soils down to the depth of $1 \mathrm{~m}$, and $22.1 \mathrm{t} \mathrm{C} \mathrm{ha}^{-1}$ in the forest floor (De Vos et al., 2015). For example, in the Nordic region the SOC stocks down to $1 \mathrm{~m}$ of soil fluctuates from $<50$ to more than $200 \mathrm{t} \mathrm{C} \mathrm{ha}^{-1}$ 
(Gundersen et al., 2014), and it was increasing with the growing temperature from the north to the south of country. The results obtained by various authors also differ regarding the profile distribution of SOC in forest soils (Jobbagy and Jackson, 2000; Rumpel and Kögel-Knabner, 2011; De Vos et al., 2015).

Our earlier studies showed that the SOC stocks distribution in soils of pine forests depends on the habitat and soil type (Ostrowska et al., 2010; Porębska and Ostrowska, 2013). In Poland, the SOC stocks down to the depth of $1 \mathrm{~m}$ vary from ca. 40 to 120 $\mathrm{t} \mathrm{ha}^{-1}$ in different pine forest sites depending on the quality of stands examined. At the same time, we noted that despite the passing of 30 years, i.e. change in the age of stands from 50-55 to $80-85$ years, the SOC stocks in soils did not increase. Contrastingly, some declining trends were observed (Porębska and Ostrowska, 2013). Thus, we concluded that the lack of SOC stocks increase in soils over the ca. 30-year period might be due to unfavourable growth conditions (water and nutrient deficit) and to the variability of the conditions in different regions of Poland.

There are very few studies in the literature documenting long-term changes in the SOC stocks in the soil profile. Therefore the objective of this study was to analyze the changes in soil SOC stocks in the pine forest over 26 years. The study was carried out on the same plots as in the past, for the same soil type and in this way, we aimed to assess whether the SOC stocks changed with the age of the stand and to assess its vertical distribution over time.

\section{Materials and methods}

\subsection{Study sites}

The study was carried out in the Przymuszewo Forest Inspectorate in Tucholskie Forests, situated in the Middle Pomerania of northern Poland. The area is covered with glaciofluvial sands and gravels forming an outwash plain of the Brda river in the forefront of the moraine zone of the Pomeranian stage of northern Poland's glaciation. The geomorphologically uniform area is built by $25 \mathrm{~m}$ thick sand and gravel layers deposited on several ten-meter-thick layers of boulder clays. The relief may generally be characterized by two lobes, western and eastern, of a weakly undulating surface of the outwash plain, and a fragment of a deeply incised postglacial tunnel valley, filled with waters of the Gardliczno and Nawionek lakes. Varying in size kettle holes are encountered in the north-eastern part of the study area (Borzyszkowski, 1993a). The soil cover of the study area is typical of many outwash plain areas in Poland. There dominate soils developed from postglacial sandy-gravely sediments whose morphology varies only slightly owing to the land relief. The groundwater in sands and gravels occurs at the depths between 10 and $20 \mathrm{~m}$ and, locally, even deeper (Borzyszkowski, 1993b).

The study area embraces ca. 600 ha located between the following coordinates $53^{\circ} 54^{\prime} 45^{\prime \prime}-53^{\circ} 53^{\prime} 35^{\prime \prime} \mathrm{N}$ latitude and $17^{\circ} 31^{\prime} 15^{\prime \prime}-$ 17'33'32”'E longitude. Comprehensive studies of soils and stands were conducted in the years 1990-1992 (Integrated Monitoring Station Bory Tucholskie Forest, 1993), offering baseline for other studies, which were continued under various aspects over the following years. In this work, we focused on the accumulation of organic carbon in one soil type, which is widespread in the area examined and also in other coniferous forest habitats in Poland. In 2018, we established 10 study sites in the close vicinity of the sites selected in the years 1992 and 2008. All the soils examined were dominated by sand (more than $80 \%$ ) with a humus layer of 2-7 cm and according to WRB (2014) were classified as Albic Brunic Arenosols (Dystric). All the study sites were located within the coniferous forest (CF) site under the 75-90-year-old stand with Scots pine (Pinus sylvestris L.) as a dominating species (Leucobryo-Pinetum, Mat. 1962). Vegetation are mainly phytocoenoses pine forest, developed as replacement communities in pine monocultures used as a way of managing forest areas for approx. 200 years (Sienkiewicz 1993). Historically, the Tucholskie Forests have been managed for pine plantations for a couple hundreds of years. The mean annual temperature was $7.5^{\circ} \mathrm{C}$ in $1992,8.3^{\circ} \mathrm{C}$ in 2008 and $9.1^{\circ} \mathrm{C}$ in 2018 , while the annual precipitation: $511 \mathrm{~mm}, 582 \mathrm{~mm}$ and $520 \mathrm{~mm}$, respectively.

\subsection{Soil sampling}

Ten soil profiles down to the depth of $1 \mathrm{~m}$ were dug at following divisions: 102a, 118b, 122a, 123c, 139c, 141c, 145a, 163a, $164 \mathrm{c}$ and $166 \mathrm{~d}$. We described the morphology of each profile and measured the thickness of genetic horizons. The soil was sampled from each profile from individual genetic horizons (Ofh, $\mathrm{AE}, \mathrm{Bv}, \mathrm{BvC}$ and $\mathrm{C}$ ), including undisturbed structure samples collected into $100 \mathrm{~cm}^{3}$ stainless steel cylinders to determine bulk density.

\subsection{Soil analysis}

Bulk density (BD) was determined by the weight method in the structurally undisturbed samples collected from soil genetic horizons. Soil texture was determined by the aerometric method (Ostrowska et al., 1991).

Soils samples air-dried at room temperature were passed through the $2 \mathrm{~mm}$ sieve. The content of soil carbon was determined in powdered samples using TOC-5000A autoanalyzer (Shimadzu model), with ignition at $1000^{\circ} \mathrm{C}$ (in 2018 and 2008). In 1992, the content of soil carbon was determined by Tyurin method. The principle of Tyurin method is an oxidation of soil organic carbon with excess potassium dichromate in a concentrated sulphuric acid. Non-consumed potassium dichromate is determined by redox titration with ferrous ammonium sulphate. As no inorganic carbon was present in the samples, all measured soil carbon was assumed to constitute soil organic carbon (SOC). The content of total nitrogen (TN) was determined by Kjeldahl method, while $\mathrm{pH}$ in $\mathrm{H}_{2} \mathrm{O}$ in the 1:2.5 soil:water suspension.

The soil $\mathrm{C}$ contents determined by Tyurin method were recalculated to the contents detected with the use of dry combustion method, by applying a conversion factor of 1.05 provided by Jankauskas et al. (2006), according to which a paired power regression among these methods was $\mathrm{r}^{2}=0.947$.

The organic carbon stocks in the $0-40 \mathrm{~cm}$ layer were obtained by multiplying the carbon content, soil bulk density and thickness of individual horizons encountered in that soil layer 
and summing up the respective stocks of all soil horizons. For calculating the stocks, account was taken of the following horizons: Ofh, $\mathrm{AE}$ and $\mathrm{Bv}$, however, when the Bv horizon was deeper reaching only a part of its thickness was used in calculations; and in the opposite case the BvC horizon was partly taken into account.

The SOC stocks of soil profile down to $1 \mathrm{~m}$ was calculated by summing up the respective OC stocks of all horizons of that profile. In the calculations only a part of $\mathrm{C}$ horizon was taken into account to obtain a thickness of the layer to a depth of $1 \mathrm{~m}$. It was possible to calculate the SOC stocks to the depth of $1 \mathrm{~m}$ only for data acquired in the years 2008 and 2018, since the study in 1992 did not embrace the level of parent rock.

Given the high homogeneity of the soils examined, and the need for referring the results obtained in 2018 to the archive data, account was taken of the average values $(n=10)$ of soil properties determined for the respective genetic horizons. The significance of differences between years was determined on the basis of analysis of variance and Tukey's HSD test (honest significant difference test).

Chemical analyses were conducted at the accredited laboratory of the Institute of Environmental Protection - National Research Institute.

\section{Results}

The soils have a typical sequence of genetic horizons: Ofh$\mathrm{AE}-\mathrm{Bv}-\mathrm{BvC}-\mathrm{C}$. The thickness of the organic horizon Ofh has practically remained unchanged since the onset of the study, fluctuating between 3 and $7 \mathrm{~cm}$ at present, whereas in 1992 it was oscillating between 2 and $6 \mathrm{~cm}$ (Table 1). The humic AE horizon is from 5 to $16 \mathrm{~cm}$ thick, what is considered typical of local variability of the entire soil cover, taking into account, for example, the local land relief. The thickness of the horizon Bv ranges from 17 to $35 \mathrm{~cm}$ what is typical of formation of the horizon in the cover zone of periglacial transformations.

Minor morphological changes, observed in soil profiles, provide evidence of the stability of both the organic and mineral horizons within the period 1992-2018. The texture of soils sampled from all the profiles is typical of sandy soils, with insignificant enrichment in silt and clay particles only in subsurface layers, which may reach down to the Bv horizon at the deepest. The morphological homogeneity of soils is corroborated by the low variability in their bulk density (Table 1).

All the soils examined belong to acid soils with $\mathrm{pH}$ in the Ofh horizon oscillating in the range 3.7-4.4, in the AE horizon - from 4.0 to 4.4, in the Bv horizon - from 4.7 to 5.1, likewise as in the BvC and C horizons (Table 1).

The mean contents of SOC and TN as well as the mean SOC stocks in genetic horizons decrease with increasing depth of soil profile (Table 2). The SOC stocks levels calculated for genetic horizons in the past and present are difficult to compare due to spatial diversity even within the same soil type. The thickness of soil horizons varies between profiles by a few or even a dozen $\mathrm{cm}$, which affects the amount of SOC stocks in a given horizon. Therefore, the amount of SOC stocks stored in the 0-40 cm layer, and in the whole soil profile down to the depth of $1 \mathrm{~m}$, was adopted as a more objective indicator.

A declining trend was observed for the average SOC stocks from 0 to $40 \mathrm{~cm}$ which decreased by ca. 10\% between 1992 and 2008, whereas, in the following period between 2008 and 2018, by a further $5 \%$ (Table 3 ). It can be estimated that over the period examined the SOC accumulation decreased by $0.28 \mathrm{tha}^{-1} \mathrm{y}^{-1}$, although the regression line was not significant (negative trend, $\mathrm{R}^{2}=0.084$ ).

Table 1

Physical properties of the horizons of Albic Brunic Arenosol (Dystric) in 1992 and 2018

\begin{tabular}{|c|c|c|c|c|c|c|c|c|c|c|}
\hline \multirow[t]{2}{*}{ Horizon } & \multirow[t]{2}{*}{ Parameter } & \multicolumn{7}{|c|}{$1992(n=10)$} & \multicolumn{2}{|c|}{$2018(\mathrm{n}=10)$} \\
\hline & & $\begin{array}{l}\text { Sand } \\
\%\end{array}$ & $\begin{array}{l}\text { Clay } \\
\%\end{array}$ & $\begin{array}{l}\text { Silt } \\
\%\end{array}$ & $\begin{array}{l}\text { Thickness } \\
\mathrm{cm}\end{array}$ & $\begin{array}{l}\mathrm{BD} \\
\mathrm{g} \mathrm{cm}^{-3}\end{array}$ & $\mathrm{pH}$ & $\begin{array}{l}\text { Thickness } \\
\mathrm{cm}\end{array}$ & $\begin{array}{l}\mathrm{BD} \\
\mathrm{g} \mathrm{cm}^{-3}\end{array}$ & $\mathrm{pH}$ \\
\hline \multirow[t]{2}{*}{ Ofh } & Mean \pm SD & & & & $4 \pm 1$ & $0.10 \pm 0.02$ & & $5 \pm 1$ & $0.10 \pm 0.02$ & \\
\hline & $\min -\max$ & & & & $2-6$ & $0.09-0.15$ & $3.4-3.9$ & $3-7$ & $0.08-0.13$ & $3.7-4.4$ \\
\hline \multirow[t]{2}{*}{$\mathrm{AE}$} & Mean \pm SD & $89 \pm 3$ & $5 \pm 3$ & $5 \pm 2$ & $9 \pm 3$ & $1.35 \pm 0.08$ & & $12 \pm 3$ & $1.35 \pm 0.09$ & \\
\hline & $\min -\max$ & 83-93 & $2-11$ & $4-9$ & $4-14$ & $1.22-1.47$ & $3.4-4.3$ & $5-16$ & 1.18-1.49 & $4.0-4.4$ \\
\hline \multirow[t]{2}{*}{ Bsv } & Mean \pm SD & $90 \pm 4$ & $6 \pm 4$ & $4 \pm 2$ & $5 \pm 1$ & $1.45 \pm 0.07$ & & n.d. & n.d. & n.d. \\
\hline & $\min -\max$ & 81-94 & $3-16$ & $1-6$ & $4-8$ & $1.39-1.60$ & $4.0-4.8$ & & & \\
\hline \multirow[t]{2}{*}{$\mathrm{Bv}$} & Mean \pm SD & $93 \pm 2$ & $4 \pm 2$ & $3 \pm 1$ & $16 \pm 7$ & $1.50 \pm 0.21$ & & $25 \pm 5$ & $1.56 \pm 0.07$ & \\
\hline & $\min -\max$ & 90-95 & $1-6$ & $1-5$ & $7-27$ & $1.45-1.59$ & $4.5-5.0$ & $17-35$ & $1.45-1.67$ & $4.7-5.1$ \\
\hline \multirow[t]{2}{*}{$\mathrm{BvC}$} & Mean \pm SD & $96 \pm 1$ & $2 \pm 2$ & $2 \pm 1$ & $12 \pm 6$ & $1.59 \pm 0.05$ & & $22 \pm 7$ & $1.63 \pm 0.04$ & \\
\hline & $\min -\max$ & 95-97 & $0-5$ & $0-3$ & $5-20$ & $1.50-1.65$ & $4.7-6.0$ & $13-35$ & $1.57-1.73$ & $4.7-5.2$ \\
\hline \multirow[t]{2}{*}{ C } & Mean \pm SD & n.e. & n.e. & n.e. & n.e. & n.e. & n.e. & $37 \pm 9$ & $1.60 \pm 0.08$ & \\
\hline & $\min -\max$ & & & & & & & $25-52$ & $1.41-1.68$ & $4.8-5.1$ \\
\hline
\end{tabular}

Abbreviations: SD - standard deviation, BD - bulk density, n.d. - not determined, n.e. - no examined 
Table 2

SOC and TN contents, C/N values as well as SOC stocks in soil horizons in 1992, 2008 and 2018 (mean values and standard deviation, mean: $\mathrm{n}=10$ for $1992, \mathrm{n}=7$ for $2008, \mathrm{n}=10$ for 2018)

\begin{tabular}{llllll}
\hline Year & Horizon & $\begin{array}{l}\text { SOC } \\
\%\end{array}$ & TN & C:N & $\begin{array}{l}\text { SOC stocks } \\
\text { t ha }{ }^{-1}\end{array}$ \\
\hline 1992 & Ofh & $35.58 \pm 3.53 \mathrm{a}$ & $1.091 \pm 0.151 \mathrm{a}$ & $32.6 \pm 3.61$ & $14.81 \pm 4.95 \mathrm{a}$ \\
& AE & $1.64 \pm 0.62 \mathrm{~b}$ & $0.069 \pm 0.042 \mathrm{~b}$ & $23.7 \pm 5.4$ & $19.24 \pm 8.20 \mathrm{a}$ \\
& Bvs & $1.05 \pm 0.27$ & $0.041 \pm 0.010$ & $25.6 \pm 4.5$ & $8.02 \pm 2.76$ \\
& Bv & $0.55 \pm 0.22 \mathrm{~b}$ & $0.024 \pm 0.007 \mathrm{~b}$ & $22.0 \pm 3.0$ & $11.87 \pm 5.02 \mathrm{a}$ \\
& BvC & $0.18 \pm 0.08 \mathrm{~b}$ & n.d. & n.d. & $3.52 \pm 2.72 \mathrm{a}$ \\
& C & n.d. & n.d. & n.d. & n.d. \\
& Ofh & $42.18 \pm 2.74 \mathrm{~b}$ & $1.099 \pm 0.208 \mathrm{a}$ & $39.4 \pm 6.3$ & $20.70 \pm 5.65 \mathrm{a}$ \\
& AE & $0.95 \pm 0.16 \mathrm{a}$ & $0.030 \pm 0.008 \mathrm{a}$ & $32.7 \pm 7.5$ & $17.56 \pm 3.66 \mathrm{a}$ \\
& Bv & $0.30 \pm 0.15 \mathrm{a}$ & $0.016 \pm 0.005 \mathrm{ab}$ & $17.5 \pm 5.3$ & $10.87 \pm 5.00 \mathrm{a}$ \\
& BvC & $0.08 \pm 0.01 \mathrm{a}$ & $0.009 \pm 0.003$ & $8.0 \pm 0.9$ & $4.58 \pm 1.36 \mathrm{a}$ \\
& C & $0.08 \pm 0.01$ & $0.005 \pm 0.004$ & n.d. & $3.77 \pm 1.45$ \\
Ofh & $41.24 \pm 3.54 \mathrm{~b}$ & $1.165 \pm 0.140 \mathrm{a}$ & $35.7 \pm 3.8$ & $20.65 \pm 6.29 \mathrm{a}$ \\
AE & $0.82 \pm 0.32 \mathrm{a}$ & $0.034 \pm 0.012 \mathrm{a}$ & $25.0 \pm 6.6$ & $13.53 \pm 7.25 \mathrm{a}$ \\
Bv & $0.30 \pm 0.09 \mathrm{a}$ & $0.015 \pm 0.004 \mathrm{a}$ & $20.1 \pm 3.2$ & $11.65 \pm 4.01 \mathrm{a}$ \\
& BvC & $0.09 \pm 0.05 \mathrm{a}$ & $0.006 \pm 0.003$ & $15.6 \pm 5.5$ & $2.92 \pm 1.59 \mathrm{a}$ \\
& C & $0.03 \pm 0.02$ & $0.003 \pm 0.001$ & $9.5 \pm 3.0$ & $1.56 \pm 0.73$ \\
\hline
\end{tabular}

Abbreviations: SOC - soil organic carbon, TN - total nitrogen; the same letters in soil horizons mean that differences between the year are not significant (significant at $\mathrm{p}<0.05$ )
Table 3

Organic carbon stocks (t ha-1) in the $0-40 \mathrm{~cm}$ soil layer in 1992, 2008 and 2018 (mean: $\mathrm{n}=10$ for 1992 , $\mathrm{n}=7$ for $2008, \mathrm{n}=10$ for 2018 )

\begin{tabular}{lll}
\hline Year & Mean SOC stocks & $\begin{array}{l}\text { min }- \text { max SOC } \\
\text { stocks }\end{array}$ \\
\hline 1992 & $53.6 \pm 13.8$ a & $37.4-70.6$ \\
2008 & $48.4 \pm 6.0$ a & $42.2-57.5$ \\
2018 & $46.0 \pm 11.9$ a & $27.2-67.0$ \\
\hline
\end{tabular}

The same letters mean that differences between the year are not significant
When comparing the contents of SOC found in the entire soil profile between 2008 and 2018, it was noted that the average SOC stocks down to $1 \mathrm{~m}$ was $57.5 \mathrm{t} \mathrm{ha}^{-1}$ in 2008 while in 2018 was lower by ca. $9 \%$ and attained $52.3 \mathrm{t} \mathrm{ha}^{-1}$, but the differences were not significant. In 2008, the SOC stocks in the Ofh horizon accounted for $36 \%$ of the stocks down to $1 \mathrm{~m}$, ca. $30 \%$ in the $\mathrm{AE}$ horizon, 19\% in the Bv horizon, whereas, in 2018, the respec- tive amounts were: $40 \%, 27 \%$ and $23 \%$, consequently, $85-90 \%$ of carbon accumulated in the soil occurred in the above horizons. The SOC stocks in the $0-40 \mathrm{~cm}$ layer accounted for ca. $84-88 \%$ of the SOC pool down to $1 \mathrm{~m}$. Mean values of SOC stocks for soil horizons in 2008 and 2018 are presented in Fig. 1.

The distribution of SOC in soil profile was similar in 2008 and 2018 (Fig. 2), however, the contribution of Ofh and Bv ho-

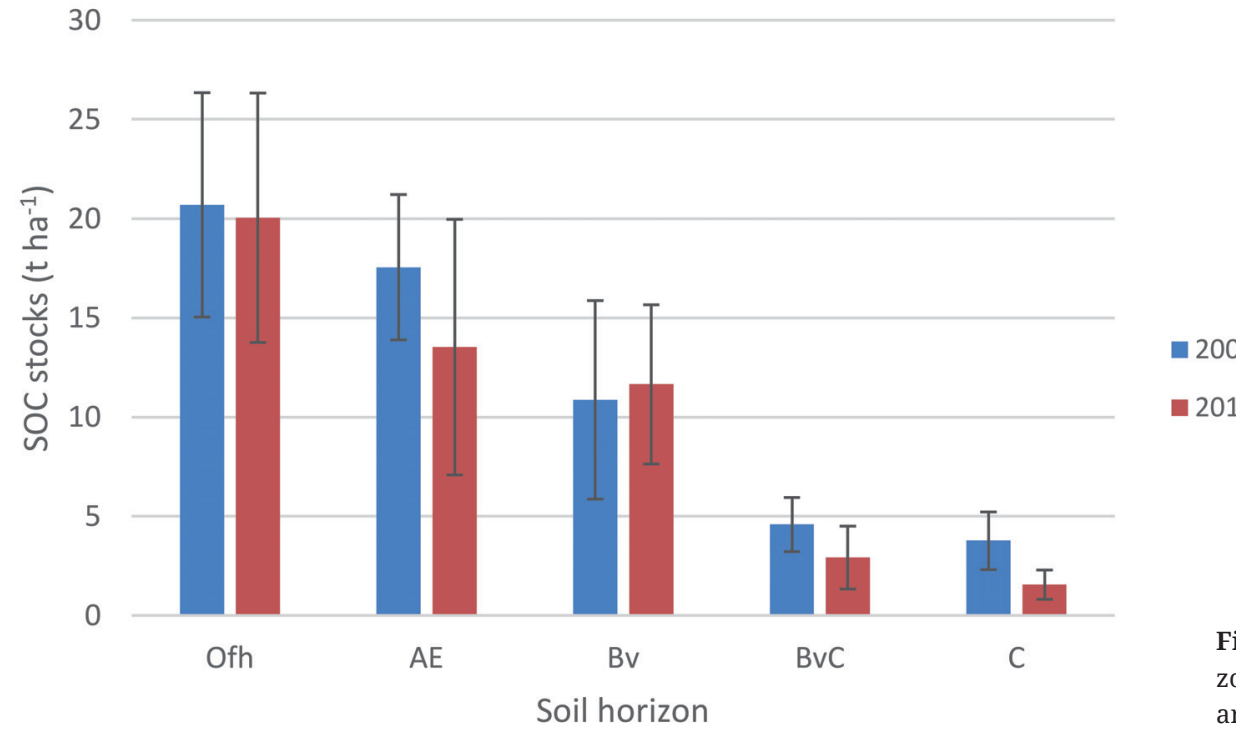

Fig. 1. Mean soil organic carbon stocks in soil horizons in 2008 and 2018 (error bars represent standard deviation) 


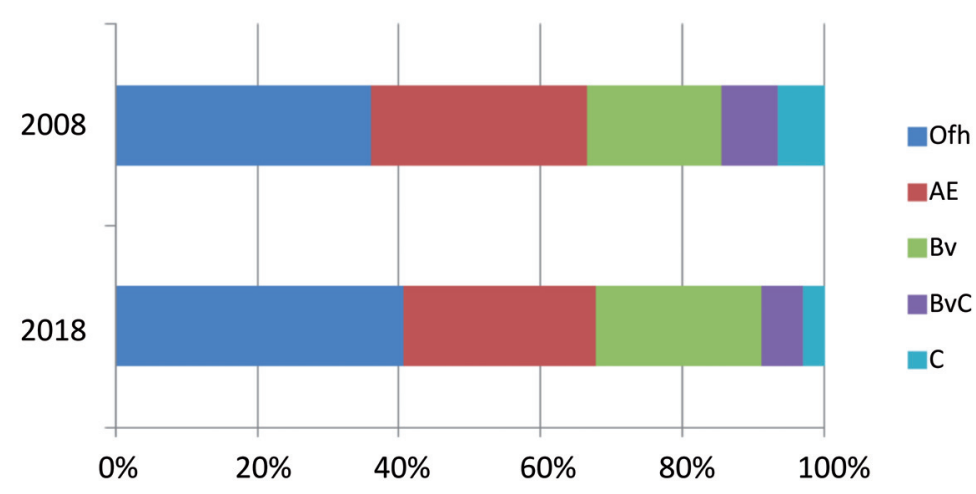

rizons was slightly higher in 2018, and that of $\mathrm{AE}, \mathrm{BvC}$ and $\mathrm{C}$ horizons - lower, which testifies to a lower rate of organic matter migration to $\mathrm{BvC}$ and $\mathrm{C}$ horizons and this may be related to water condition depending on the rainfall and temperature.

\section{Discussion}

The research was carried out on the plots in one forest complex (Tucholskie Forest), in Scots pine stands, for one type of soil to minimize spatial variability connected with different soil types and forest sites. The $\mathrm{C}$ accumulation proceeds successively from the soil surface down into the soil profile. The vertical distribution of SOC stocks in soils of coniferous forest sites depends on soil type and site quality (Ostrowska et al., 2010; Porębska and Ostrowska, 2013). The results of the study, carried out in the pine forest with Albic Brunic Arenosol (Dystric) soil developed from sands, show that $80-90 \%$ of SOC stocks is stored in the main plant rooting zone, i.e. to the depth of $40 \mathrm{~cm}$, while $40 \%$ of SOC stocks fall for the organic horizon. According to Jobbagy and Jackson (2000), the vertical distribution of SOC stocks is similar in soils of both deciduous and coniferous forests, i.e. ca. $50 \%$ SOC is stored in the $0-20 \mathrm{~cm}$ layer, ca. $70 \%$ down to the depth of $40 \mathrm{~cm}$, while the remaining up to $30 \%$ in the $40-100 \mathrm{~cm}$ layer. Rumpel and Kögel-Knabner (2011) highlighted the possibility for the accumulation of considerable amounts of $\mathrm{C}$ in subsoil layers, below $40 \mathrm{~cm}$, reporting that, in some ecosystems, the half of $\mathrm{C}$ stabilized in soils is stored in subsoil horizons.

The SOC stocks down to $1 \mathrm{~m}$ in the Albic Brunic Arenosol (Dystric) soil is $52.3 \mathrm{t} \mathrm{ha}^{-1}$ and is contained in the range of values found earlier for other pine forest in Poland (Ostrowska et al., 2010; Porębska and Ostrowska, 2013). According to Baritz et al. (2010), the SOC stocks in soils of the European forests ranges from 1.3 to $70.8 \mathrm{t} \mathrm{C} \mathrm{ha-1}^{-1}$ for the O-layer, and from 11.3 to $126.3 \mathrm{t}$ $\mathrm{C} \mathrm{ha}^{-1}$ for the mineral soil $0-20 \mathrm{~cm}$. In the Nordic region, the SOC stocks down to $1 \mathrm{~m}$ varies from $<50$ to more than $200 \mathrm{t} \mathrm{C} \mathrm{ha}^{-1}$ (Gundersen et al., 2014), while in the Bavarian forests, the average SOC stocks in the first $1 \mathrm{~m}$ layer is $9.8 \mathrm{~kg} \mathrm{~m}^{-2}$ (Wiesmeier et al., 2013). According to Achat et al. (2015), the average SOC stocks in the whole organic plus mineral soil profile for temperate European forests reaches $95 \mathrm{t} \mathrm{C} \mathrm{ha}^{-1}$, while according to De Vos et al. (2015), average SOC stocks achieves in mineral soil $108 \mathrm{t} \mathrm{C} \mathrm{ha}^{-1}$ and $22 \mathrm{t} \mathrm{C} \mathrm{ha}^{-1}$ in the forest bottom.

\section{Ofh

Thus, the values of SOC stocks may differ even quite considerably between authors, depending on the conditions of stand growth (climatic and soil) and stand age as well as the methods of determination. Soils are sampled from layers varying in thickness or individual genetic horizons, and the content of soil $\mathrm{C}$ is determined using either dry or wet combustion methods, while coefficients for recalculation to compare the results obtained by the above methods vary from 1.05 to 1.2 (Łabętowicz et al., 1997; Jankauskas et al., 2006; Józefowska and Miechówka, 2011; Barancikova and Makovnikova, 2015).

The SOC stocks estimated at a given time do not indicate whether and to what extent that stock increases/decreases during the stand growth. Generally, soil C accumulation depends on the decomposition rate of organic matter and the capacity for $\mathrm{C}$ migration down the soil profile so the stocks of $\mathrm{C}$ in the soil are affected by the balance between $C$ input from vegetation and $C$ losses as a result of decomposition (Matos et al., 2010; Stergiadi et al., 2016; Ziegler et al., 2017). The C stocks in the soil declines when there is a change in the production cycle. Restoring the SOC pool to the level accumulated in the previous production cycle requires about 50 year-long period of stand growth (Stevens and van Wesemael, 2008) and, afterwards, the C stocks increases with the increasing stand age (Seely et al., 2010; Liu et al., 2017; Bečvářová et al., 2018). Conversely, Chen et al. (2013) suggest that the SOC stocks in the surface soil layer achieve a steady level after ca. 20 years, and then maintain a stable level, which depends on $\mathrm{C}$ input and organic matter decomposition. Our results provide evidence that in pine stands, which at the onset of the study, in 1992, were 50-65-year-old, the SOC stocks did not increase after almost three decades of stand growth, quite the contrary, a declining trend was observed. Similar trends were noted in our previous studies carried out in other types of forest sites (Porębska and Ostrowska, 2013).

Losses of SOC from soils were reported by various authors (Conant et al., 2008; von Lützow and Kögel-Knaber, 2009; Melillo et al., 2011; Prietzel and Christophel, 2014), who ascribed the losses to increasing temperatures. Smith et al. (2007) provided evidence that annual $\mathrm{C}$ losses in forest soils in Central Europe fluctuated by ca. $0.05 \%$. Causes underlying these losses may be linked both to a decreased biomass input to the soil surface and enhanced biomass decomposition with $\mathrm{CO}_{2}$ emission to the atmosphere. The decomposition rate of organic matter on the soil surface, which conditions its migration down 
into the soil profile, was generally estimated based on the rate of decrease in the $\mathrm{C} / \mathrm{N}$ ratio. However, the increased input of anthropogenic $\mathrm{N}$ to the soil environment, which was observed over the past decades, significantly decreases the value of the above ratio (Ostrowska and Porębska, 2015). Thus, we suggest that with the recent level of climate change and $\mathrm{CO}_{2}$ emission to the atmosphere, the input of biomass to the soil surface may decrease, while its decomposition rate increase. The observed declining trend for the SOC stocks may be even more noticeable in the subsequent cycles of stand production.

\section{Conclusions}

Based on the results obtained, it can be stated that about $85-90 \%$ of the total SOC stocks is stored in $0-40 \mathrm{~cm}$, i.e. in the rooting layer, while ca. $40 \%$ of the stocks is accumulated in the organic horizon. In Scots pine forest, the SOC stocks down to the depth of $40 \mathrm{~cm}$ in Albic Brunic Arenosol (Dystric) sandy soil decreased by ca. $15 \%$ over 26 years, i.e. throughout the stand growth from the age of ca. 50-65 to 75-90 years. Over the past 10 years, the SOC stocks decreased by $5 \%$ in the $0-40 \mathrm{~cm}$ layer, and by $9 \%$ in the $0-100 \mathrm{~cm}$ layer. The observed decrease in the SOC stocks is statistically insignificant. This may indicate the relative stabilization of the SOC stocks in mature stands. Nevertheless, the research shows a decreasing trend which should be examined in the future.

A general conclusion is that forest stands, especially during the vegetation season, have the potential to decrease $\mathrm{CO}_{2}$ emission to the atmosphere and $\mathrm{C}$ accumulation in the tree biomass. Thus, forest stands may, to a certain extent, counterbalance $\mathrm{CO}_{2}$ input/output to and from the atmosphere by $\mathrm{C}$ sequestration and accumulation in biomass. However, our results point out that, for Central Europe poor sandy forest soils could not be of particular importance for $\mathrm{CO}_{2}$ withdrawal from the atmosphere, though they constitute a large reservoir of organic carbon.

\section{Acknowledgments}

The study was supported by the subsidies for statutory activities provided by the Ministry of Science and Higher Education of the Republic of Poland. The authors thank Professor Apolonia Ostrowska for her useful comments and substantive discussion. We also thank Ms Izabela Grzegorczyk for her help in field soil sampling and Mr Mirosław Cimoch for his help in sample preparation and laboratory analyses. The authors greatly appreciate the reviewers as their comments were very helpful to improvement of the manuscript.

\section{References}

Achat, D.L., Fortin, M., Landmann, G., Ringeval, B., Augusto, L., 2015. Forest soil carbon is threatened by intensive biomass harvesting. Scientific Reports 5, 15991. https://doi.org/10.1038/srep15991

Allen, D.E., Singh, B.P., Dalal, R.C., 2011. Soil health indicators under climate change: A review of current knowledge. [In:] Soil Health and
Climate Change. Eds. Singh, B., Cowie, A., Chan, K. Soil Biology, vol 29. Springer, Berlin, Heidelberg https://doi.org/10.1007/978-3-64220256-8_2

Barancikova, G., Makovnikova, J., 2015. Comparison of two methods of soil organic carbon determination. Polish Journal of Soil Science 48(1), 47-56. http://dx.doi.org/10.17951/pjss.2015.48.1.47

Baritz, R., Seufert, G., Montanarella, L., Van Ranst, E., 2010. Carbon concentrations and stocks in forest soils of Europe. Forest Ecology and Management 260(3), 262-277. https://doi.org/10.1016/ j.foreco.2010.03.025

Bečvářová, P., Horváth, M., Šarapatka, B., Zouhar, V., 2018. Dynamics of soil organic carbon (SOC) content in stands of Norway spruce (Picea abies) in central Europe. iForest 11, 734-742. https://doi.org/10.3832/ ifor2521-011

Błońska, E., Lasota, J., 2017. Soil organic matter accumulation and carbon fractions along a moisture gradient of forest soils. Forests 8, 448. https://doi.org/10.3390/f8110448

Borzyszkowski, J., 1993a. General characteristics of the Bory Tucholskie Integrated Monitoring Station. [In:] Integrated Monitoring Station Bory Tucholskie. IOŚ Warszawa, Poland, 45-56 (in Polish).

Borzyszkowski, J., 1993b. Soil morphology and soil texture in the Integrated Monitoring Station Bory Tucholskie. [In:] Integrated Monitoring Station Bory Tucholskie, IOŚ Warszawa, Poland, 65-73 (in Polish).

Bouriaud, O., Don, A., Janssens, I.A., Marin, G., Schulze, E.D., 2019. Effects of forest management on biomass stocks in Romanian beech forests. Forest Ecosystems 6:19, https://doi.org/10.1186/s40663-0190180-4

Callesen, I., Stupak, I., Georgiadis, P., Johannsen, V.K., Řstergaard, H.S., Vesterdal, L., 2015. Soil carbon stock change in the forests of Denmark between 1990 and 2008. Geoderma Regional 5, 169-180. https://doi.org/10.1016/j.geodrs.2015.06.003

Chen, G.S., Yang, Z.J., Gao, R., Xie, J.S., Guo, J.F., Huang, Z.Q., Yang, Y.S., 2013. Carbon storage in a chronosequence of Chinese fir plantations in southern China. Forest Ecology and Management 300, 68-76. https://doi.org/10.1016/j.foreco.2012.07.046

Conant, R.T., Drijber, R.A., Haddix, M.L., Parton, W.J., Paul, E.A., Plante, A.F., Six, J., Steinweg, J.M., 2008. Sensitivity of organic matter decomposition to warming varies with its quality. Global Change Biology 14, 868-877. https://doi.org/10.1111/j.1365-2486.2008.01541.x

De Vos, B., Cools, N., Ilvesniemi, H., Vesterdal, L., Vanguelova, E., Carnicelli, S., 2015. Benchmark values for forest soil carbon stocks in Europe: Results from a large-scale forest soil survey. Geoderma 251252, 33-46. https://doi.org/10.1016/j.geoderma.2015.03.008

Dovydenko, N., 2004. Contents of carbon in soil of selected pine and spruce stands occurring on post-agricultural lands. Leśne Prace Badawcze 2, 49-66 (in Polish).

Gross, C.D., James, N.J., Harrison, R.B., 2018. Thinning treatments reduce deep soil carbon and nitrogen stocks in a coastal Pacific Northwest forest. Forests 9(5), 238. https://doi.org/10.3390/f9050238

Gruba, P., Socha, J., 2016. Effect of parent material on soil acidity and carbon content in soils under silver fir (Abies alba Mill.) stands in Poland. Catena 140, 90-95. https://doi.org/10.1016/j.catena.2016.01.020

Grüneberg, E., Ziche, D., Wellbrock, N., 2014. Organic carbon stocks and sequestration rates of forest soils in Germany. Global Change Biology 20, 2644-2662. https://doi.org/10.1111/gcb.12558

Gundersen, P. (Ed.), Ginzburg Ozeri, S., Vesterdal, L., Bárcena, T.G., Sigurdsson, B.D., Stefansdottir, H.M., Lazdina, D., 2014. Forest soil carbon sink in the Nordic region. Frederiksberg: Department of Geosciences and Natural Resource Management, University of Copenhagen, Denmark, IGN Report, 37 pp. www.ign.ku.dk

Hagedorn, F., Machwitz, M., 2007. Controls on dissolved organic matter leaching from forest litter grown under elevated atmospheric $\mathrm{CO}_{2}$. Soil Biology and Biochemistry 39(7), 1759-1769. https://doi. org/10.1016/j.soilbio.2007.01.038 
Hou, G., Delang, C.O., Lu, X., Gao, L., 2019. Soil organic carbon storage varies with stand ages and soil depths following afforestation. Annals of Forest Research 62(1), 3-20. https://doi.org/10.15287/ afr.2018.1294

Integrated Monitoring Station Tucholskie Forest,1993. Ostrowska A. Ed. Environmental Protection Institute, Warsaw, Poland, p. 155 (Stacja Kompleksowego Monitoringu Środowiska Bory Tucholskie. Instytut Ochrony Środowiska, Warszawa, in Polish).

Jankauskas, B., Slepetiene, A., Jankauskiene, G., Fullen, M.A., Booth, C.A., 2006. A comparative study of analytical methodologies to determine the soil organic matter content of Lithuanian Eutric Albeluvisols. Geoderma 136, 763-773. https://doi.org/10.1016/ j.geoderma.2006.05.015

Jobbagy, E.G., Jackson, R.B., 2000. The vertical distribution of soil organic carbon and its relation to climate and vegetation. Ecological Applications 10(2), 423-436. https://doi.org/10.1890/10510761(2000)010[0423:TVDOSO]2.0.CO;2

Józefowska, A., Miechówka, A., 2011. Comparison of the results of determining the organic carbon in soils of the Carpathian Foothills obtained by the Tiurin and dry combustion method (thermal method). Roczniki Gleboznawcze - Soil Science Annual 62(1), 65-69 (in Polish).

Liu, Y., Lei, P., Xiang, W., Yan, W., Chen, X., 2017. Accumulation of soil organic $\mathrm{C}$ and $\mathrm{N}$ in planted forests fostered by tree species mixture. Biogeosciences 14, 3937-3945. https://doi.org/10.5194/bg-14-39372017

López-Marcos, D., Martinez-Riuz, C., Turrión, M-B., Jonard, M., Titeux, H., Ponette, Q., Bravo, F., 2018. Soil carbon stocks and exchangeable cations in monospecific and mixed pine forests. European Journal of Forest Research 137(6), 831-847. https://doi.org/10.1007/s10342018-1143-y

Łabętowicz, J., Stępień, G., Ożarowski, G., 1997. Factors determining differences in organic $\mathrm{C}$ content determined by the Tiurin method and the direct method of dry combustion. Roczniki Gleboznawcze - Soil Science Annual 48(3/4), 74-81 (in Polish).

Martin, M.P., Wattenbach, M., Smith, P., Meersmans, J., Jolivet, C., Boulonne, L., Arrouays, D., 2011. Spatial distribution of soil organic carbon stock in France. Biogeosciences 8(5), 1053-1065. https://doi. org/10.5194/bg-8-1053-2011

Martinik, A., Knott, R., Krejza, J., Černý, J., 2018. Biomass production of Betula pendula stands regenerated in the region of allochthonous Picea abies dieback. Silva Fennica 52(5), article id 9985. https://doi. org/10.14214/sf.9985

Matos, E.S., Freese, D., Ślązak, A., Bachmann, U., Veste, M., Hüttl, R.F., 2010. Organic-carbon and nitrogen stocks and organic carbon fractions in soil under mixed pine and oak forest stands of different ages in NE Germany. Journal of Plant Nutrition and Soil Science 173(5), 654-661. https://doi.org/10.1002/jpln.200900046

Melillo, J.M., Butler, S., Johnson, J., Mohan, J., Steudler, P., Lux, H., Burrows, E., Bowles, F., Smith, R., Scott, L., Vario, Ch., Hill, T., Burton, A., Zhou, Y-M., Tang, J., 2011. Soil warming, carbon-nitrogen interactions, and forest carbon budgets. PNAS 108(23), 9508-9512. https:// doi.org/10.1073/pnas.1018189108

Moffat, A.J, 2003. Indicators of soil quality for UK forestry. Forestry 76(5), 547-568. https://doi.org/10.1093/forestry/76.5.547

Ostrowska, A., Gawliński S., Szczubiałka, Z., 1991. Methods of analysis and assessment of soil and plant properties. Catalog. Warszawa, IOŚ (in Polish)

Ostrowska, A., Porębska, G., 2015. Assessment of the $\mathrm{C} / \mathrm{N}$ ratio as an indicator of the decomposability of organic matter in forest soils. Ecological Indicators 49, 104-109. https://doi.org/10.1016/ j.ecolind.2014.09.044

Ostrowska, A., Porębska, G., Kanafa, M., 2010. Carbon accumulation and distribution in profiles of forest soils. Polish Journal of Environmental Studies 19(6), 1307-1315.
Porębska, G., Ostrowska, A., 2013. Assessment of C stock in forest soils in Poland over the last 30 years. Polish Journal of Environmental Studies 22(2), 503-510.

Prietzel, J., Christophel, D., 2014. Organic carbon stocks in forest soils of the German Alps. Geoderma 221-222, 28-39. https://doi.org/10.1016/ j.geoderma.2014.01.021

Rumpel, C., Kögel-Knabner, I., 2011. Deep soil organic matter - A key but poorly understood component of terrestrial C cycle. Plant and Soil 338(1-2), 143-158. https://doi.org/10.1007/s11104-010-0391-5

Schindlbacher, A., de Gonzalo, C., Díaz Pinés, E., Gorría, P., Matthews, B., Inclán, R., Zechmeister Boltenstern, S., Rubio, A., Jandl, R., 2010. Temperature sensitivity of forest soil organic matter decomposition along two elevation gradients. Journal of Geophysical Research 115, G03018, https://doi.org/10.1029/2009JG001191

Schoenholtz, S.H., Van Miegroet, H., Burger, J.A., 2000. A review of chemical and physical properties as indicators of forest soil quality: challenges and opportunities. Forest Ecology and Management 138(1-3), 335-356. https://doi.org/10.1016/S0378-1127(00)00423-0

Seely, B., Welham, C., Blanco, J.A., 2010. Towards the application of soil organic matter as indicator of forest ecosystem productivity; Deriving thresholds, developing monitoring systems and evaluating practices. Ecological Indicators 10(5), 999-1008. https://doi.org/10.1016/ j.ecolind.2010.02.008

Shukla, M.K., Lal, R., Ebinger, M., 2006. Determining soil quality indicators by factor analysis. Soil and Tillage Research 87(2), 194-204. https://doi.org/10.1016/j.still.2005.03.011

Sienkiewicz, J., 1993. Forest plant communities in the area of the Integrated Monitoring Station Bory Tucholskie. [In:] Integrated Monitoring Station Bory Tucholskie, IOŚ Warszawa, Poland, 111-124 (in Polish)

Smith, P., Chapman, S., Scott, W., Black, H., Wattenbach, M., Milne, R., Campbell, C., Lilly, A., Ostle, N., Levy, P.E., Lumsdon, D.G., Millard, P., Towers, W., Zaehle, S., Smith, J.U., 2007. Climate change cannot be entirely responsible for soil carbon loss observed in England and Wales 1978-2003, Global Change Biology 13(12), 2605-2609. https:// doi.org/10.1111/j.1365-2486.2007.01458.x

Stergiadi, M., van der Perk, M., de Nijs, T.C.M., Marc, F.P., Bierkens, M.F.P., 2016. Effects of climate change and land management on soil organic carbon dynamics and carbon leaching in northwestern Europe. Biogeosciences 13, 1519-1536. https://doi.org/10.5194/bg-13-1519-2016

Stevens, A., van Wesemael, B., 2008. Soil organic carbon stock in the Belgian Ardennes as affected by afforestation and deforestation from 1868 to 2005. Forest Ecology and Management 256(8), 1527-1539. https://doi.org/10.1016/j.foreco.2008.06.041

von Lützow, M., Kögel-Knaber, I., 2009. Temperature sensitivity of soil organic matter decomposition - what do we know? Biology and Fertility of Soils 46, 1-15. https://doi.org/10.1007/s00374-009-0413-8

Wickland, K.P., Neff, J.C., 2008. Decomposition of soil organic matter from boreal black spruce forest: environmental and chemical controls. Biogeochemistry 87(1), 29-47. https://doi.org/10.1007/s10533007-9166-3

Wiesmeier, M., Prietzel, J., Barthold, F., Spörlein, P., Geuß, U., Hangen, E., Reischl, A., Schilling, B., von Lützow, M., Kögel-Knaber, I., 2013. Storage and drivers of organic carbon in forest soils of southeast Germany (Bavaria) - Implications for carbon sequestration. Forest Ecology and Management 295, 162-172. https://doi.org/10.1016/ j.foreco.2013.01.025

WRB 2014. World Reference Base for Soil Resources. FAO, Rome.

Yigini, Y., Panagos, P., 2016. Assessment of soil organic carbon stocks under future climate and land cover changes in Europe. Science of the Total Environment 557-558, 838-850. https://dx.doi.org/10.1016/ j.scitotenv.2016.03.085

Zhang, X., Zhang, X., Han, H., Shi, Z., Yang, X., 2019. Biomass accumulation and carbon sequestration in an age-sequence of Mongolian pine plantations in Horqin sandy land, China. Forests 10, 197. https://doi.org/10.3390/f10020197 
Ziegler, S.E., Benner, R., Billings, S.A., Edwards, K.A., Philben, M., Zhu, X., Laganiere, J., 2017. Climate warming can accelerate carbon fluxes without changing soil carbon stocks. Frontiers in Earth Science 5:2. https://doi.org/10.3389/feart.2017.00002
Zornoza, R., Acosta, J.A., Bastida, F., Dominguez, S.G., Toledo, D.M., Faz, A., 2015. Identification of sensitive indicators to assess the interrelationship between soil quality, management practices and human health. Soil 1, 173-185. https://doi.org/10.51.94/soil-1-173-2015

\section{Słowa kluczowe}

Gleby leśne

Zapas węgla

Dystrybucja w profilu

\section{Zmiany zapasu węgla organicznego w glebach porośniętych przez drzewostany sosnowe (Pinus sylvestris L.) w północnej Polsce w okresie 26 lat}

\section{Streszczenie}

Zmiany zawartości węgla organicznego w glebach (SOC) w długim czasie są istotne dla obiegu węgla, szczególnie w odniesieniu do ocieplenia prognozowanego w nadchodzących dekadach. Możliwość zwiększenia sekwestracji węgla w glebach leśnych jest dyskusyjna, ponieważ ocieplenie klimatu może przyspieszyć obieg węgla, co ma wpływ na jego akumulację i zapas. Celem badań była ocena zmian zapasu SOC i jego pionowej dystrybucji w leśnej glebie rdzawej z cechami bielicowania w okresie 26 lat. Próbki gleb pobrano w dojrzałym drzewostanie sosnowym w Borach Tucholskich w północnej Polsce i porównano wyniki badań uzyskanych w roku 1992, 2008 i 2018. Oznaczono węgiel organiczny, azot całkowity i gęstość objętościową w poszczególnych poziomach genetycznych. Zapasy SOC obliczono w warstwach gleby $0-40 \mathrm{~cm}$ i $0-100 \mathrm{~cm}$. Stwierdzono, że w okresie 26 lat wzrostu drzewostanu, tj. od ok. 50-65 do ok. 75-90 lat, zapas SOC do głębokości $40 \mathrm{~cm}$ zmniejszył się o ok. 15\%. W ciągu ostatnich dziesięciu lat zapas SOC zmniejszył się o 5\% w warstwie 0-40 cm i o $9 \% \mathrm{w}$ warstwie 0-100 cm. Zmniejszenie zapasu SOC jest statystycznie nieistotne i może wskazywać na względną stabilizację zapasu SOC w dojrzałych drzewostanach sosnowych. Około 84-88\% całkowitego zapasu SOC znajdowało się w warstwie 0-40 cm, z czego 40\% w poziomie organicznym. Uzyskane wyniki wskazują, że w najbliższych latach prawdopodobnie nie należy spodziewać się wzrostu zapasu SOC w glebach leśnych wytworzonych z piasków, jakkolwiek lasy i gleby leśne stanowią duży rezerwuar węgla organicznego. Zaobserwowany malejący trend w zapasie SOC wymaga dalszych obserwacji. 